\title{
INCREASING THE PRODUCTIVITY AND WATER USE EFFICIENCY OF APPLE TREES AS AFFECTED BY DRIP IRRIGATION AND MULCHING IN NEW RECLAIMED SOILS Mady, A.A. \\ Water Management and Irrigation System Research Institute, National Water Research Center, Cairo Egypt
}

\begin{abstract}
Two field experiments were conduced during 2003 and 2004 seasons to study the effect of three irrigation rates of $13.584,10.188$ and $6.792 \mathrm{~m}^{3} /$ tree/year $\left(\mathrm{l}_{1}, \mathrm{l}_{2}\right.$ and $\mathrm{I}_{3}$ ) and two mulching types viz, black polethylene and dry cut grass, (M1, M2, M0) comparing to bare soil respectively as well as their interactions on production, fruit quality, water consumptive use (WCU), crop coefficient (Kc) and water use efficiency (WUE) of anna apple trees bedded on Malus rootstock and grown in loamy sand soil at El-Bostan region, El-Beheira governorate. Reduced drip irrigation regime from 13.584 to $6.792 \mathrm{~m}^{3} /$ tree/year significantly decreased fruit yield associated with decreasing fruit set and increasing preharvest fruit drop, and also decreasing average fruit weight length, diameter, total soluble solids (TSS\%), water consumptive use and crop coefficient $(\mathrm{Kc})$ values. The highest values always belonged to $I_{1}$ and $I_{2}$ rates in both seasons. While, the highest values of fruit firmness, water use efficiency (WUE) $\mathrm{kg} / \mathrm{m}^{3}$ were obtained with the deficit $\left(I_{3}\right)$ and moderate $\left(I_{2}\right)$ irrigation regimes without significant difference between them. Meanwhile, total acidity was not affected by the tested irrigation regimes.

Soil mulching with dry cut grass or black P.E produced maximum yield with good physical and chemical properties, it also decreased monthly and seasonal water consumptive use and $\mathrm{Kc}$ values but, increased water use efficiency (WUE). The interaction $(\mathrm{I} \times \mathrm{M})$ was usually significant which obtained the highest productivity, best quality, highest water use efficiency and less water consumptive use values were recorded with ( $I_{2} \times$ black $\left.P . E\right)$ and ( $I_{2} \times$ cut grass) combination treatments in the two seasons of study.

Thus, this study recommends "Anna" apple growers to use moderate irrigation rate $I_{2}$ (10.188 $\mathrm{m}^{3} /$ tree/year) under dry cut grass mulching in $\left(I_{2} \times\right.$ cut grass) combination treatment which considered the best one for obtaining maximum yield with a good quality. This treatment also reduced water consumptive use and increased water use efficiency (WUE).

Keywords: apple-drip irrigation - mulching - yield - fruit quality - water consumptive use - water use efficiency.
\end{abstract}

\section{INTRODUCTION}

"Anna" apple (Malus domestica, Borkh) is considered one of the leading apple cultivars in Egypt, being of low chilling requirements. It needed about $300-350 \mathrm{hrs}$ blew $7.2^{\circ} \mathrm{C}$ to break their bud dormancy (Zayan and Morsy, 1989). The cultivated area of Anna apple cultivar is increasing rapidly, especially during the last two decades. It reached about (65441) feddans and total annual production (578249 tons) according to MALR ( 2005).

New established apple orchards are concentrated in the new reclaimed soils at El-Nubaria and El-Bostan regions which are drip irrigated. In Egypt, although the quantity of irrigation water is available, the ideal use of 
Mady, A.A.

this water is essential. Thus, minimizing water use not only reduce production cost, especially where fertigation in normal practices, but also, help to meet the environmental regulation due to reducing the leaching of nutrients into ground water.

Increasing moisture stress reduced the actual water consumptive use as well as the productivity of Anna apple trees (El-Gendy and Abd El-Messeih, 2002). However, increasing irrigation rate (IR) from 11.76 to $17.64 \mathrm{~m}^{3}$ water/tree/year significantly increased fruit yield of pear trees and improved fruit quality and water use efficiency (Fathi, 1999).

Soil mulching plays an important role in establishment of increasing productivity and fruit quality of apple trees as well as improving soil fertility (Verma et al., 2005). Soil mulching reduces the evaporation from the upper layer of the soil and reserve the water in available form at the root zone. Moreover, soil mulching with rice straw and white plastic, reduced seasonal water consumptive use while, increased water use efficiency (WUE) of Valencia orange trees (Khalifa, 1994).

Therefore, the present work was carried out to study the effect of different irrigation regimes and types of mulches on yield, fruit quality, actual water consumptive use, crop coefficient $(\mathrm{Kc})$ and water use efficiency (WUE) of "Anna" apple trees grown in loamy sand soil under El-Bostan region conditions.

\section{MATERIAL AND METHODS}

The present investigation has been carried out on "Anna" apple trees budded on malus rootstock during two successive seasons of 2003 and 2004. The trees were grown in loamy sand soil at El-Bostan region, El-Beheira governorate, spaced at $4 \mathrm{~m}$ between rows $\times 3 \mathrm{~m}$ within rows (350 trees/fed.) and subjected to common horticultural practices of this region. Some chemical and physical properties of the experimental soil are presented in Table (1). Soil analysis was carried out according to the standard methods described by Black (1983) and Kulte (1986).

Drip irrigation system of two JR lines was used for every row of the trees (with inter emitter each $50 \mathrm{~cm}$ ) at 12 inter emitters per tree, the discharge of an emitter is $4 \mathrm{~L} / \mathrm{hr}$

The experiment consisted of irrigation treatments at three irrigation regimes $\mathrm{I}_{1}, \mathrm{I}_{2}$ and $\mathrm{l}_{3}$ at rate of $13.584,10.188$ and $6.792 \mathrm{~m}^{3}$ of water/tree/year, respectively which arranged in the main plots.

Water quantities applied per "Anna" apple tree are shown in Table (2) the other treatments were mulching materials at which three types are used; black polyethylene with 60 micron thickness and dry cut grass in $10 \mathrm{~cm}$ and bare soil. Depth of were applied on both sides of the tree line on March $1^{\text {st }}$ until the end of November. The mulching area was about $27 \mathrm{~m}^{2}$ for each replicate. The three mulching treatments were arranged in the sub plots. Nine combination treatments ( 3 irrigation $\times 3$ mulching) were replicated three times with three trees in each replicate ( 3 replication $\times 3$ trees). Thus, 81 uniform trees were selected and used in this study. The experimental treatments were designed in split plot. 
J. Agric. Sci. Mansoura Univ., 34 (6), June, 2009

Table (1): Some chemical and physical properties of the experimental soil.

\begin{tabular}{|c|c|c|c|}
\hline \multirow[t]{2}{*}{ Soil variable } & \multicolumn{3}{|c|}{ Soil depth (cm) } \\
\hline & $0-30$ & $30-60$ & $60-90$ \\
\hline $\mathrm{pH}$ & 8.2 & 8.1 & 8.2 \\
\hline $\mathrm{EC}, \mathrm{mmhos} / \mathrm{cm}$ & 1.98 & 1.24 & 1.22 \\
\hline OM\% & 0.97 & 0.85 & 0.43 \\
\hline $\mathrm{CaCO}_{3} \%$ & 18.6 & 19.3 & 19.5 \\
\hline Porosity \% & 65.28 & 55.47 & 61.89 \\
\hline Bulk density, gm/ $/ \mathrm{cm}^{3}$ & 0.92 & 1.18 & 1.01 \\
\hline \multicolumn{4}{|l|}{ Soluble cations, meq/L } \\
\hline $\mathrm{Na}^{+}$ & 4.81 & 4.26 & 3.92 \\
\hline $\mathrm{K}^{+}$ & 0.62 & 0.58 & 0.46 \\
\hline $\mathrm{Ca}^{++}$ & 9.41 & 8.27 & 7.80 \\
\hline $\mathrm{Mg}^{++}$ & 3.56 & 2.95 & 1.42 \\
\hline \multicolumn{4}{|l|}{ Soluble anions, meq/L } \\
\hline $\mathrm{Cl}^{-}$ & 10.73 & 9.46 & 8.15 \\
\hline $\mathrm{HCO}_{3}$ & 1.75 & 0.96 & 1.00 \\
\hline $\mathrm{CO}^{-} 3$ & 0.00 & 00.0 & 0.00 \\
\hline $\mathrm{SO}^{-}{ }_{4}$ & 5.92 & 5.64 & 4.45 \\
\hline \multicolumn{4}{|c|}{ Particle size distribution $\%$} \\
\hline Sand & 87.92 & 86.71 & 89.06 \\
\hline Silt & 5.63 & 6.25 & 4.98 \\
\hline Clay & 6.45 & 7.04 & 5.96 \\
\hline Textural class & Loamy sand & Loamy sand & Loamy sand \\
\hline
\end{tabular}
OM: Organic Matter

Table (2): The quantity of irrigation water applied to each "Anna" apple tree (litters) and per feddan $\left(\mathrm{m}^{3}\right)$ in the different irrigation treatments during each growing season.

\begin{tabular}{|l|c|c|c|c|c|}
\hline \multicolumn{1}{|c|}{ Months } & No. of irrigation & Time of each & \multicolumn{3}{|c|}{ Irrigation treatment L/tree } \\
\cline { 4 - 6 } & imonth & irrigation (hours) & $\mathbf{I}_{\mathbf{1}}$ & $\mathbf{I}_{\mathbf{2}}$ & $\mathbf{I}_{\mathbf{3}}$ \\
\hline Jan. & 4 & 1 & 192 & 144 & 96 \\
Feb. & 10 & 1 & 480 & 360 & 240 \\
Mar. & 10 & 2 & 960 & 720 & 480 \\
Apr. & 10 & 2.50 & 1200 & 900 & 600 \\
May & 15 & 2.50 & 1800 & 1350 & 900 \\
Jun. & 15 & 3 & 2160 & 1620 & 1080 \\
Jul. & 15 & 3 & 2160 & 1620 & 1080 \\
Aug. & 15 & 2.50 & 1800 & 1350 & 900 \\
Sept. & 10 & 2.50 & 1200 & 900 & 600 \\
Oct. & 10 & 1.50 & 960 & 720 & 480 \\
Nov. & 10 & 1 & 480 & 360 & 240 \\
Dec. & 4 & 1 & 192 & 144 & 96 \\
\hline Total amount/tree/year & - & - & 6.792 & 10.188 & 13.584 \\
(m ${ }^{3}$ ) & - & - & 2377.2 & 3565.8 & 4754.4 \\
\hline Total irrigation water/ & - & & & \\
fed./year $\left(\mathrm{m}^{3}\right.$ ) & & & & & \\
\hline
\end{tabular}

$I_{1}=12$ emitters/tree, $I_{2}=9$ emitters/tree and $I_{3}=6$ emitters/tree

Emitter discharge is $4 \mathrm{~L} / \mathrm{ha}$ 
Mady, A.A.

Measurements and determinations:

Estimating fruit set and preharvest fruit drop percentages:

On April, $10^{\text {th }}$ fruit set $\%$ was estimated by counting the total number of flowers and fruits which were developed on the selected main branches (four-years old). The number of preharvest dropped fruits was recorded after June drop, then the percentage of preharvest fruit drop (as an average) was calculated in relation to the total number of fruits harvested per trees.

Yield values:

Yields as number and weight $(\mathrm{kg})$ of fruits per tree were recorded at harvest time (June, 24 $4^{\text {th }}$ and June, 26 ${ }^{\text {th }}$ ) in 2003 and 2004 seasons, then yield (tons) per feddan was calculated.

Physical and chemical fruit properties:

Five mature fruits per tree were collected at random to determine fruit weight $(\mathrm{gm})$, length $(\mathrm{cm})$, diameter $(\mathrm{cm})$ and fruit firmness $\left(\mathrm{lb} / \mathrm{in}^{2}\right)$. Juice samples were prepared to determine total soluble solids (TSS) by using Gallilis hand refractometer and total titratable acidity $\%$ as malic acid according to A.O.A.C. (1990).

Climatological elements:

Values of the climatological elements in Table (3) were obtained from the Meterological Station at El-Dilingate. It represents the circumstances and conditions of El-Beheira Governrorate. Values of air temperature $\left({ }^{\circ} \mathrm{C}\right)$, relative humidity $(\mathrm{RH} \%)$, evaporation ( $\mathrm{mm} /$ day) and rainfall $(\mathrm{mm} /$ day) were recorded daily during the two years. While, values of other climatological elements as wind speed $(\mathrm{m} / \mathrm{sec})$, solar radiation ( $\mathrm{cal} / \mathrm{cm}^{2} /$ day) and sunshine (hours) were obtained as the normal values for a period of 20 years from 1962-1982 (FAO, 1984), then reference evapotranspiration (ETo), $\mathrm{mm} /$ day was calculated by using penman method (FAO, 1977).

Actual evapotranspiration (ETa) or water consumptive use (CU):

Soil moisture content was determined before and after each irrigation to calculate water consumptive use (CU) according to Iseraelson and Hansen (1962) by using the following equation:

$$
\mathrm{CU}=\frac{\theta_{2}-\theta_{1}}{100} \times \mathrm{Bd} \times \mathrm{D} \times \mathrm{A}
$$

Where:

$\mathrm{CU} \quad=$ Water consumptive use in each irrigation $(\mathrm{cm})$,

$\theta_{2}=$ Soil moisture percentage after irrigation (\%, d.b),

$\theta_{1}=$ Soil moisture percentage before irrigation $(\%$ d.b),

$\mathrm{Bd}=$ Soil bulk density $\left(\mathrm{g} / \mathrm{cm}^{3}\right)$,

$\mathrm{D} \quad=$ Depth of soil layer $(\mathrm{cm})$ and

A $=$ Irrigation area $\left(\mathrm{cm}^{2}\right)$. 
Table (3): The meteorological parameters of El-Dilingate Weather Station and reference evapotranspiration (ETo) during 2003 and 2004 seasons.

\begin{tabular}{|c|c|c|c|c|c|c|c|}
\hline \multirow{2}{*}{ Months } & \multicolumn{2}{|c|}{$\begin{array}{l}\text { Air temp. } \\
\quad\left({ }^{\circ} \mathrm{C}\right)\end{array}$} & \multicolumn{2}{|c|}{$\begin{array}{c}\text { Relative humidity } \\
(\%)\end{array}$} & \multirow{2}{*}{$\begin{array}{l}\text { Rain, } \\
\text { mm/day }\end{array}$} & \multirow{2}{*}{$\begin{array}{c}\text { evaporation } \\
\text { (mm/day) }\end{array}$} & \multirow[t]{2}{*}{$\begin{array}{c}\text { ETo* } \\
\text { (mm/day) }\end{array}$} \\
\hline & Max. & Min. & Max. & Min. & & & \\
\hline & \multicolumn{7}{|c|}{2003 season } \\
\hline Jan. & 22.3 & 11.8 & 74.5 & 32.4 & - & 2.1 & 2.43 \\
\hline Feb. & 19.3 & 10.7 & 74.7 & 34.5 & - & 2.1 & 2.80 \\
\hline Mar. & 21.4 & 11.4 & 87.1 & 38.2 & - & 2.2 & 3.45 \\
\hline Apr. & 24.2 & 13.6 & 88.6 & 31.9 & - & 4.2 & 4.46 \\
\hline May & 30.4 & 15.8 & 87.5 & 0.22 & - & 6.5 & 5.72 \\
\hline Jun. & 31.9 & 19.7 & 87.1 & 28.8 & - & 6.6 & 6.20 \\
\hline Jul. & 30.6 & 20.7 & 87.1 & 40.1 & - & 6.1 & 5.80 \\
\hline Aug. & 31.4 & 21.1 & 87.8 & 43.3 & - & 5.2 & 5.41 \\
\hline Sept. & 29.7 & 19.0 & 88.3 & 38.4 & - & 5.7 & 4.35 \\
\hline Oct. & 28.7 & 16.3 & 87.9 & 33.8 & - & 4.7 & 3.46 \\
\hline Nov. & 23.8 & 13.7 & 86.1 & 42.0 & - & 2.9 & 2.40 \\
\hline \multirow[t]{2}{*}{ Dec. } & 19.9 & 10.6 & 87.4 & 38.3 & 7 & 2.2 & 2.00 \\
\hline & \multicolumn{7}{|c|}{2004 season } \\
\hline Jan. & 17.5 & 8.8 & 79.3 & 40.8 & 55 & 2.2 & 2.19 \\
\hline Feb. & 19.6 & 8.8 & 83.1 & 42.8 & 27 & 2.2 & 2.75 \\
\hline Mar. & 21.7 & 10.4 & 81.7 & 34.5 & - & 3.5 & 3.71 \\
\hline Apr. & 24.3 & 11.7 & 83.7 & 30.3 & - & 4.2 & 4.53 \\
\hline May & 41.3 & 22.2 & 40.2 & 11.9 & - & 9.9 & 7.66 \\
\hline Jun. & 32.3 & 20.1 & 84.3 & 28.9 & - & 6.1 & 6.47 \\
\hline Jul. & 33.2 & 22.7 & 84.0 & 37.5 & - & 6.1 & 6.29 \\
\hline Aug. & 32.4 & 22.5 & 84.0 & 39.7 & - & 5.7 & 5.68 \\
\hline Sept. & 31.8 & 20.1 & 84.4 & 36.5 & - & 5.1 & 4.69 \\
\hline Oct. & 30.1 & 18.4 & 86.3 & 32.2 & - & 4.2 & 3.74 \\
\hline Nov. & 26.0 & 16.2 & 89.0 & 38.3 & - & 4.3 & 2.75 \\
\hline Dec. & 21.0 & 11.2 & 90.4 & 44.8 & 17 & 2.1 & 2.04 \\
\hline
\end{tabular}

${ }^{*}$ ETo according to modified penman (FAO-24 Method, 1977).

\section{Crop coefficient $(\mathrm{Kc})$ :}

Crop coefficient $(\mathrm{Kc})$ was estimated by $(\mathrm{FAO}, 1990)$ as follows :

Where:

$$
\mathrm{Kc}=\mathrm{ETa} / \mathrm{ETo}
$$
$\mathrm{KC}=$ Crop coefficient,
$\mathrm{ETa}=$ Actual evapotranspiration $(\mathrm{mm} /$ day $)$ and
ETo = Potential evapotranspiration ( $\mathrm{mm} /$ day) .

Water use efficiency (WUE)):

Water use efficiency (WUE) was calculated according to Hansen et al. (1980) by the following equation:

$$
\text { WUE }\left(\mathrm{kg} / \mathrm{m}^{3}\right)=\frac{\text { Yield }(\mathrm{kg} / \mathrm{fed} .)}{\text { Water consumptive use }\left(\mathrm{m}^{3} / \text { fed. }\right)}
$$

The obtained data were subjected to statistical analysis according to Snedecor and Cochran (1990) and LSD test at 0.05 were used for comparing between averages. 
Mady, A.A.

\title{
RESULTS AND DISCUSSION
}

\author{
Effect of drip irrigation rate (I), mulching type (M) and their interaction \\ (I $x$ M) on: \\ 1- Fruit setting and preharvest fruit drop: \\ Data in Table (4) showed that, fruit set percentage was significantly
} decreased by reduced drip irrigation rate. On the contrary, preharvest fruit drop was increased and the differences among all the tested irrigation rates were significant in both seasons. Such results might be due to lower photosynthetic rates under deficit irrigation regime (Mpelasoka et al., 2001). These results are in conformity with the findings of Behboudian et al. (1994) and George and Nissen (2002) who, indicated that, as the severity of drought increased, fruit set was reduced. The data also revealed that, black polyethylene or cut grass mulching treatment produced higher fruit set but, lower preharvest fruit drop percentage than that under bare soil without significant differences between them in $1^{\text {st }}$ and $2^{\text {nd }}$ seasons. The beneficial effects of soil mulching could be attributed to its effect on soil temperature and moisture content which affected the absorption of nutrients, especially $\mathrm{Ca}^{++}$via roots. These findings are in complete agreement with those obtained by Pande et al. (2005) on "Red Delicious" apple trees, who mentioned that, the maximum percent of fruit set was recorded under mulching treatments while, the maximum fruit drop occurred in the clean cultivation treatment. Similar results were also reported by Zayan (1991) on "Washington Navel" orange trees. However, the interaction between irrigation and mulching treatments $\left(l_{1} \times M\right)$ were significant in both seasons and the best combination treatment was ( $l_{1} \times$ black P.E) or ( $l_{1} \times$ cut grass) followed by $\left(l_{2} \times\right.$ black P.E) and ( $I_{2} \times$ cut grass) which produced more fruit set and the least preharvest fruit drop percentage.

\section{2- production:}

Concerning, the influence of drip irrigation and soil mulching treatments on production, data presented in Table (4) indicated that production of "Anna" apple trees as number and weight $(\mathrm{kg})$ of mature fruits per tree and total production (tons/fed) were gradually increased as drip irrigation level increased and the maximum significant fruit production was produced by $\left(\mathrm{I}_{1}\right)$ while, the minimum values was fruited under deficit irrigation level $\left(I_{3}\right)$. These results might be due to the role of irrigation in increasing fruit set and reducing preharvest fruit drop beside, improving average fruit weight. These findings were supported by those obtained with Higgs and Jones (1991), Hipps (1997), Shahein et al. (2002) and El-Gendy and Abd ElMesseih (2002), they found that, drought decreased fruit production of apple trees.

However, Fathi (1999) mentioned that drip irrigation at 75\% crop water requirement (CWR) increased yield of LeCont pear trees than lower or higher rates. 
Table (4): Effect of drip irrigation, mulching treatments, their interaction on fruit set, preharvest fruit drop and production of "Anna" apple trees in 2003 and 2004 seasons.

\begin{tabular}{|c|c|c|c|c|c|c|c|c|c|c|c|}
\hline \multicolumn{2}{|c|}{ Treatments } & \multirow{2}{*}{\multicolumn{2}{|c|}{$\begin{array}{c}\text { Fruit set* } \\
(\%)\end{array}$}} & \multirow{2}{*}{\multicolumn{2}{|c|}{$\begin{array}{c}\begin{array}{c}\text { Preharvest } \\
\text { fruit }\end{array} \\
\text { drop (\%) }\end{array}$}} & \multicolumn{6}{|c|}{ production } \\
\hline \multirow{2}{*}{$\begin{array}{l}\text { Irrig. } \\
\text { rate }\end{array}$} & \multirow{2}{*}{$\begin{array}{c}\text { Mulching } \\
\text { type }\end{array}$} & & & & & \multicolumn{2}{|c|}{$\begin{array}{c}\text { No. of } \\
\text { fruits/tree }\end{array}$} & \multicolumn{2}{|c|}{$\mathrm{Kg} /$ tree } & \multicolumn{2}{|c|}{ Tons/fed. } \\
\hline & & 2003 & 2004 & 2003 & 2004 & 2003 & 2004 & 2003 & 2004 & 2003 & 2004 \\
\hline $\mathrm{l}_{1}$ & $\begin{array}{l}\text { Bare soil } \\
\text { Cut grass } \\
\text { Black } \\
\text { P.E. }\end{array}$ & \begin{tabular}{|l|}
20.41 \\
24.59 \\
25.87
\end{tabular} & $\begin{array}{l}22.37 \\
24.42 \\
26.11\end{array}$ & \begin{tabular}{|l|}
9.55 \\
7.99 \\
6.99 \\
\end{tabular} & $\begin{array}{l}9.04 \\
7.45 \\
6.18\end{array}$ & $\begin{array}{l}157 \\
175 \\
186\end{array}$ & $\begin{array}{l}151 \\
179 \\
182\end{array}$ & $\begin{array}{l}23.27 \\
30.83 \\
31.93\end{array}$ & $\begin{array}{l}23.38 \\
31.28 \\
32.26\end{array}$ & $\begin{array}{c}8.15 \\
10.79 \\
11.17\end{array}$ & $\begin{array}{c}8.18 \\
10.95 \\
11.29\end{array}$ \\
\hline $\mathrm{I}_{2}$ & $\begin{array}{l}\text { Bare soil } \\
\text { Cut grass } \\
\text { Black } \\
\text { P.E. }\end{array}$ & \begin{tabular}{|l|}
17.30 \\
21.91 \\
23.21
\end{tabular} & $\begin{array}{l}19.35 \\
23.05 \\
24.58\end{array}$ & \begin{tabular}{|c|}
12.67 \\
9.93 \\
9.80
\end{tabular} & $\begin{array}{l}11.89 \\
9.61 \\
9.02\end{array}$ & $\begin{array}{l}134 \\
161 \\
170\end{array}$ & $\begin{array}{l}129 \\
156 \\
165\end{array}$ & $\begin{array}{l}18.06 \\
26.58 \\
27.33\end{array}$ & $\begin{array}{l}17.24 \\
25.10 \\
26.60\end{array}$ & $\begin{array}{l}6.32 \\
9.30 \\
9.57\end{array}$ & $\begin{array}{l}5.97 \\
8.98 \\
9.31\end{array}$ \\
\hline $\mathrm{I}_{3}$ & $\begin{array}{l}\text { Bare soil } \\
\text { Cut grass } \\
\text { Black } \\
\text { P.E. }\end{array}$ & \begin{tabular}{|l|}
15.91 \\
19.64 \\
20.78
\end{tabular} & $\begin{array}{l}17.84 \\
21.22 \\
23.18\end{array}$ & \begin{tabular}{|l|}
14.79 \\
12.45 \\
12.00
\end{tabular} & $\begin{array}{l}14.68 \\
12.06 \\
11.62\end{array}$ & $\begin{array}{l}118 \\
137 \\
139\end{array}$ & $\begin{array}{l}109 \\
136 \\
135\end{array}$ & $\begin{array}{l}13.15 \\
20.00 \\
20.37\end{array}$ & $\begin{array}{l}12.49 \\
18.57 \\
19.11\end{array}$ & $\begin{array}{l}4.60 \\
7.00 \\
7.12\end{array}$ & $\begin{array}{l}4.37 \\
6.50 \\
6.69\end{array}$ \\
\hline L.S.L & D. 0.05 & 1.773 & 2.111 & 1.316 & 1.207 & 12.70 & 11.65 & 1.521 & 2.983 & 0.532 & 1.170 \\
\hline Average & $\begin{array}{l}\mathrm{I}_{1} \\
\mathrm{I}_{2} \\
\mathrm{I}_{3}\end{array}$ & \begin{tabular}{|l|}
23.62 \\
20.81 \\
18.78 \\
\end{tabular} & $\begin{array}{l}24.30 \\
22.33 \\
20.75\end{array}$ & \begin{tabular}{|c|}
8.18 \\
10.80 \\
13.08 \\
\end{tabular} & $\begin{array}{c}7.56 \\
10.17 \\
12.79 \\
\end{array}$ & $\begin{array}{l}173 \\
155 \\
131 \\
\end{array}$ & $\begin{array}{l}171 \\
150 \\
127\end{array}$ & $\begin{array}{l}28.68 \\
23.99 \\
17.84 \\
\end{array}$ & $\begin{array}{l}28.97 \\
22.98 \\
16.72 \\
\end{array}$ & $\begin{array}{l}10.04 \\
8.40 \\
6.24\end{array}$ & $\begin{array}{c}10.14 \\
8.09 \\
5.85\end{array}$ \\
\hline L.S.L & D. 0.05 & 0.915 & 1.769 & 0.923 & 0.766 & 9.83 & 9.06 & 1.031 & 1.298 & 0.359 & 0.691 \\
\hline Average & $\begin{array}{l}\text { Bare soil } \\
\text { Cut grass } \\
\text { Black } \\
\text { P.E. }\end{array}$ & $\begin{array}{l}17.87 \\
22.05 \\
23.29\end{array}$ & $\begin{array}{l}19.85 \\
22.90 \\
24.62\end{array}$ & \begin{tabular}{|c|}
12.34 \\
10.12 \\
9.51
\end{tabular} & $\begin{array}{l}11.87 \\
9.71 \\
8.94\end{array}$ & $\begin{array}{l}136 \\
158 \\
165\end{array}$ & $\begin{array}{l}130 \\
157 \\
161\end{array}$ & $\begin{array}{l}18.16 \\
25.80 \\
26.54\end{array}$ & $\begin{array}{l}17.70 \\
24.98 \\
25.99\end{array}$ & $\begin{array}{l}6.36 \\
9.03 \\
9.29\end{array}$ & $\begin{array}{l}6.17 \\
8.81 \\
9.10\end{array}$ \\
\hline L.S & כ. 0.05 & 1.104 & 0.914 & 0.706 & 0.692 & 6.19 & 5.68 & 0.838 & 1.935 & 0.293 & 0.694 \\
\hline
\end{tabular}

$I_{1}, I_{2}$ and $I_{3}=13.584,10.188$ and $6.792 \mathrm{~m}^{3}$ irrigation water/tree/year, respectively.

Soil mulching material was applied on March, $1^{\text {st }}$ in both seasons.

* Fruit set $\%$ in April, $10^{\text {th }}$.

With respect to the effect of soil mulching on yield, data in Table (4) reflected that, yield as number of fruits and weight $(\mathrm{kg})$ per tree as well as ton/fed. was significantly higher under black P.E or dry cut grass mulching treatment than that under bare soil (unmulched). However, differences between them were not significant. This hold true in both seasons. This might be due to keeping soil moisture and availability of nutrients associated with mulches resulted in higher fruit retention and less fruit drop leading to producing a higher yield. Similar results were obtained by Zayan et al. (1994), Pande et al. (2005), Singh et al. (2005), Tahir et al. (2005) and Verma et al. (2005) they found that soil mulches with black P.E and other organic material improved productivity of apple trees due to increased soil moisture and nutrient uptake.

Data in Table (4) cleared that, the interaction $(\mathrm{I} \times \mathrm{M})$ was significant and the highest fruit yield was obtained by using high and moderate irrigation regimes (13.584 and $10.188 \mathrm{~m}^{3} /$ tree/year, respectively) under both black P.E and dry cut grass mulch in ( $l_{1} \times$ black P.E), ( $l_{1} \times$ cut grass), ( $l_{2} \times$ black P.E) and ( $I_{2} \times$ cut grass) combination treatments while, unmulched trees under deficit irrigation level in ( $l_{3} \times$ bare soil) treatment produced lower yield in 2003 
and 2004 seasons. Economically, ( $I_{2} \times$ cut grass) was considered the suitable combination treatment for improving productivity of "Anna" apple trees (26.58 and $25.10 \mathrm{~kg} /$ tree in 2003 and 2004 seasons, respectively). Furthermore, saving $25 \%$ of applied water by using moderate irrigation regime 10.188 $\mathrm{m}^{3} /$ trees/year $\left(I_{2}\right)$, it means less irrigation

water, less cost, less draining water and low cost and benefits of applying dry cut grass as organic matter to the soil after mulching period.

\section{3- Physical and chemical fruit properties:}

Data in Table (5) show average fruit weight, length, diameter, firmness, TSS and acidity as affected by irrigation rate (I), mulching treatment (M) and their interaction ( $\times \mathrm{M})$.

Table (5): Effect of drip irrigation, mulching treatments, their interaction on physical and chemical properties of "Anna" apple fruits in 2003 and 2004 seasons.

\begin{tabular}{|c|c|c|c|c|c|c|c|c|c|c|c|c|c|}
\hline \multicolumn{2}{|c|}{ Treatments } & \multicolumn{2}{|c|}{$\begin{array}{c}\text { Av. fruit } \\
\text { weight (gm) }\end{array}$} & \multicolumn{2}{|c|}{$\begin{array}{l}\text { Fruit } \\
\text { length } \\
\text { (cm) }\end{array}$} & \multicolumn{2}{|c|}{$\begin{array}{c}\text { Fruit } \\
\text { diameter } \\
(\mathbf{c m})\end{array}$} & \multicolumn{2}{|c|}{$\begin{array}{c}\text { Fruit } \\
\text { firmness } \\
\text { lb/in² }\end{array}$} & \multicolumn{2}{|c|}{$\begin{array}{c}\text { TSS } \\
\%\end{array}$} & \multicolumn{2}{|c|}{$\begin{array}{c}\text { Acidity } \\
\%\end{array}$} \\
\hline $\begin{array}{l}\text { Irrig. } \\
\text { rate }\end{array}$ & $\begin{array}{c}\text { Mulching } \\
\text { type }\end{array}$ & 2003 & 2004 & 2003 & 2004 & 2003 & 2004 & 2003 & 2004 & 2003 & 2004 & 2003 & 2004 \\
\hline \multirow{3}{*}{$\mathrm{I}_{1}$} & Bare soil & 1 & 5 & 7.30 & 7.37 & 6.82 & 6.86 & 10.46 & 9.81 & 40 & 0 & 0.533 & 0.453 \\
\hline & Cut & & & 7.69 & 7.67 & 7.23 & 7.18 & 9.34 & 8.96 & & & & 0.473 \\
\hline & & 17 & & 7.61 & 7.60 & 7.17 & 7.15 & 9.15 & 8.83 & 13.27 & & & 0.495 \\
\hline \multirow{3}{*}{$\mathrm{I}_{2}$} & Bare soil & 134.82 & 133.79 & 7.17 & 7.12 & 6.68 & 6.65 & 10.85 & 10.57 & 11.93 & 12.27 & 0.549 & 0.518 \\
\hline & Cut grass & 164.11 & 16 & 7.48 & 7.45 & 7.14 & 7.08 & 9.87 & 9.52 & 13.20 & 13.53 & & 0.486 \\
\hline & Bla & 160.74 & & 7.39 & 7.31 & 6.97 & 6.91 & 9.68 & 9.40 & 12.73 & 12.60 & & 0.500 \\
\hline \multirow{3}{*}{$l_{3}$} & & 112. & & 6.29 & 6.33 & 5.95 & 5.98 & 11.24 & 10.95 & 11.60 & 3 & & 0.522 \\
\hline & & & & 7.22 & & 6.76 & 6.67 & 10.62 & 10.36 & 12.47 & 12.80 & & 0.513 \\
\hline & Black P.E. & 146.36 & & 7.30 & 7.17 & 6.84 & 6.78 & 10.43 & 10.14 & 12.20 & 12.47 & 0.554 & 0.518 \\
\hline \multicolumn{2}{|c|}{ L.S.D. 0.05} & 10.644 & 8.731 & 0.264 & 0.181 & 0.260 & 0.202 & N.S & 0.688 & 0.532 & 0.347 & N.S & N.S \\
\hline \multirow{3}{*}{ Average } & $l_{1}$ & 165.37 & 166.80 & 7.53 & 7.55 & 7.07 & 7.06 & 9.65 & 9.20 & 13.06 & 13.40 & 0.502 & 0.474 \\
\hline & $\mathrm{I}_{2}$ & 153.22 & 151.56 & 7.35 & 7.29 & 6.93 & 6.88 & 10.13 & 9.83 & 12.62 & 12.80 & 0.530 & 0.501 \\
\hline & $\mathrm{I}_{3}$ & 134.84 & 132.09 & 6.94 & 6.88 & 6.52 & 6.48 & 10.76 & 10.48 & 12.09 & 12.40 & 0.545 & 0.518 \\
\hline \multicolumn{2}{|c|}{ L.S.D. 0.05} & 9.079 & 5.342 & 0.234 & 0.128 & 0.207 & 0.145 & N.S & 0.649 & 0.332 & 0.206 & N.S & N.S \\
\hline \multirow{4}{*}{ Average } & Bare soil & 131.81 & 134.66 & 6.92 & 6.97 & 6.48 & 6.50 & 10.85 & 10.44 & 11.98 & 12.33 & 0.544 & 0.498 \\
\hline & Cut grass & 162.03 & 158.29 & 7.46 & 7.42 & 7.04 & 6.98 & 9.94 & 9.61 & 13.06 & 13.40 & 0.506 & 0.491 \\
\hline & Black P.E. & 159.60 & 157.50 & 7.43 & 7.36 & 6.99 & 6.95 & 9.75 & 9.46 & 12.73 & 12.87 & 0.527 & 0.504 \\
\hline & L.S.D. 0.05 & 4.448 & 5.098 & 0.101 & 0.097 & 0.122 & 0.107 & N.S & 0.199 & 0.308 & 0.205 & N.S & N.S \\
\hline
\end{tabular}

$I_{1}, I_{2}$ and $I_{3}=13.485,10.188$ and $6.792 \mathrm{~m}^{3}$ irrigation water/tree/year, respectively.

Soil mulching material were applied on March, $1^{\text {st }}$ in both seasons.

3-a. Average fruit weight and size:

It is clear from Table (5) that, fruit weight, length and diameter were significantly decreased by reducing the rate of irrigation and the smallest fruits were produced under deficit irrigation rate. Effect of deficit irrigation on reduced mean fruit weight and size could be due to reduce fruit cell enlargement through reduced fruit turgor early in the season and to decrease cell water content (Mpelasok et al., 2001). Furthermore, Behbudian et al. (1994) concluded that, reduced fruit size under deficit irrigation may be due to less assimilate availability through decreased photosynthesis rate (Pn). Similar results were obtained by Eble et al. (1993), Atkinson et al. (2000) Naor et al. (2001), George and Nissen (2002) Shahein et al. (2002) and Abd El- 
Messeih and El-Gendy (2004), who found that fruit size was markedly increased by irrigation.

As shown in Table (5), average fruit weight and its dimensions (length and diameter) were improved by both mulch materials. Cut grass produced heaviest and largest fruit followed by black P.E, then came the control (bare soil). The positive effect of mulches in improving fruit weight and size could be attributed to

ideal soil moisture content and supply of balanced nutrition (Verma et al., 12005). These results are in line with those obtained by Pande et al. (2005), Singh et al. (2005) and Tahir et al. (2005) on apple trees.

Moreover, the interaction ( $\times \mathrm{M})$ was significant in both seasons and maximum fruit weight and size were produced with ( $l_{1} \times$ cut grass), $\left(l_{1} \times\right.$ black P.E) and ( $\mathrm{I}_{2} \times$ cut grass) treatments. Meanwhile, the minimum values came from $\left(l_{3} \times\right.$ bare soil) treatment.

\section{3-b. Fruit firmness:}

As for fruit firmness $\left(\mathrm{lb} / \mathrm{in}^{2}\right)$, data obtained in Table (5) revealed that raising drip irrigation rate and using soil mulching led to decreased fruit firmness. The differences were only significant in the second season. This reduction in fruit firmness may be due to the increase in fruit size and increase its water content. However, the interaction ( $\mathrm{x}$ M) was only significant in the second season and the firm fruits came from $\left(I_{3} \times\right.$ bare soil) where, $\left(l_{1} \times\right.$ black P.E) gave less fruit firmness. These results are in harmony with those of Abd El-Messeih and El-Gendy (2004) reported that, deficit irrigation induced significantly higher fruit firmness. Moreover, Zayan et al. (1994) mentioned that, the values of fruit firmness of "Anna" apple were decreased by rice straw and black P.E mulching treatment. On the contrary, Tahir et al. (2005) reported that, soil mulching increased "Aroma" apple fruit firmness.

\section{3-c. Total soluble solids (TSS) and total acidity:}

It is clear that, TSS value had the same trend of fruit weight and size as influenced by drip irrigation and mulching treatments. The highest values were recorded with high irrigation rate $\left(13.584 \mathrm{~m}^{3} /\right.$ tree/year), while the least values belonged to deficit irrigation one $\left(6.792 \mathrm{~m}^{3} /\right.$ tree/year $)$ due to reduced net photosynthesis rate $(\mathrm{Pn})$ under drought condition. Similar results were obtained by Abd El-Messieh and El-Gendy (2004). In addition, the mulching treatment showed a significant increase in TSS value. Cut grass treatment recorded the maximum values followed by black P.E. On the other hand, the minimum values were recorded under bare soil. These findings are in agreement with the observations of Hifny et al. (1994), on "Banaty" grapevine and Zayan et al. (1994), on "Anna" apple trees. The interaction was significant and the highest TSS values obtained with ( $l_{1} \times$ cut grass), ( $l_{1} \times$ black P.E) and ( $I_{2} \times$ cut grass) treatments where, the least values obtained with ( $I_{3} \times$ bare soil) treatment in both seasons.

Data also exhibited that, total acidity was not significantly affected by all irrigation and mulching treatments as well as their interaction in the two seasons. Similar conclusion was also achieved by Zayan (1991), Zeerban (2004) and El-Henawy (2006). 
Mady, A.A.

Conclusively, irrigated "Anna" apple trees with moderate rate of $10.188 \mathrm{~m}^{3} /$ tree/year under dry cut grass mulch in ( $\mathrm{I}_{2} \times$ cut grass $)$ combination treatment was considered the best one. This treatment not only increased tree yield but also improved fruit quality, specially average fruit weight and size as well as TSS value.

\section{4- Water consumptive use (WCU):}

Regarding, the effect of drip irrigation and mulching treatments and their interaction on monthly and total water consumptive use (TWCU) for "Anna" apple trees, the data of both seasons illustrated in Fig. (1) and Table (6) showed that, monthly values of water consumptive use were gradually increased and reached maximum values during June and July, then declined from August to December. These could be attributed to luxuriant growth of "Anna" apple trees in this period. This trend was found to be true under all mulching and irrigation treatments. The data also showed that, monthly values of water consumptive used of "Anna" apple trees under soil mulches with black P.E or dry cut grass were less. Meanwhile, the highest values were observed under unmulched one (bare soil). These results may be due to the role of mulches in reducing evaporation and keeping soil moisture at root zone to a long period. In addition, both soil mulching treatments significantly reduced total consumptive use $\mathrm{m}^{3} / \mathrm{fed}$. as compared to bare soil in the two seasons of study as shown in Table (6).

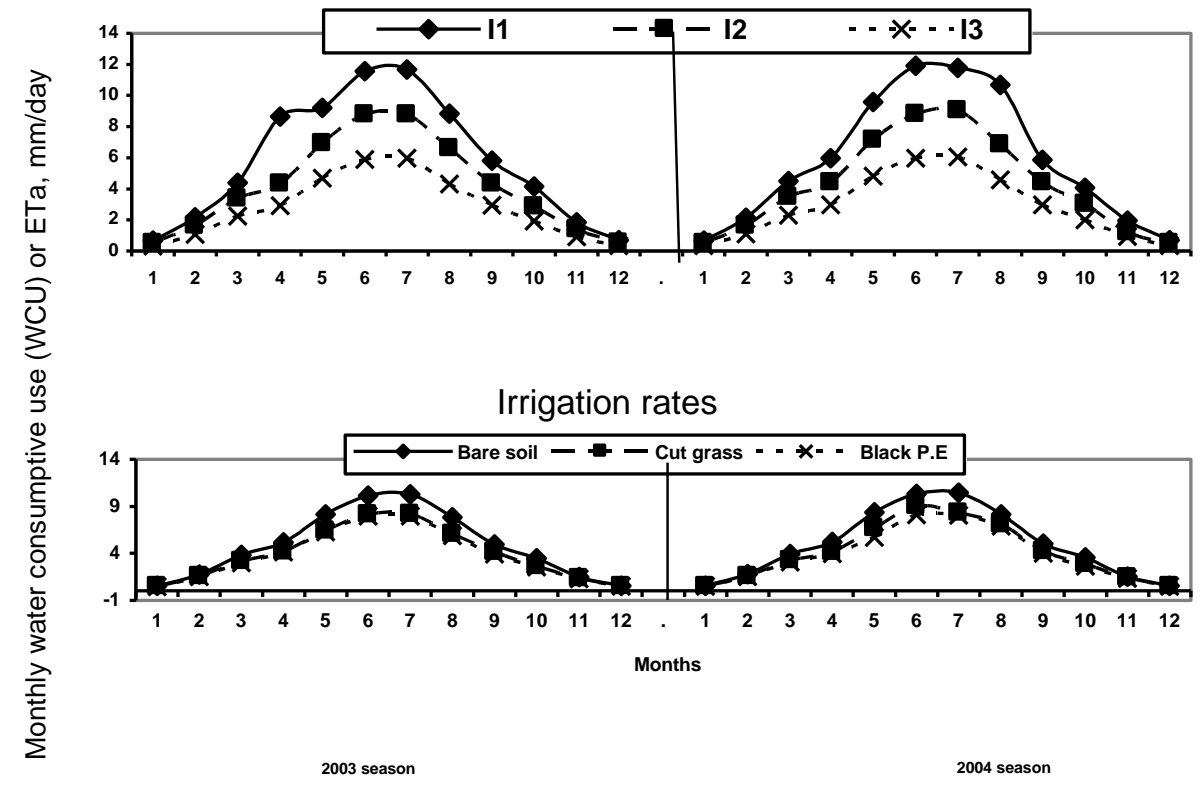

Mulching rates

Fig. (1): Effect of irrigation and mulching treatments on monthly water consumptive use $\mathrm{mm} /$ day of Anna apple trees during 2003 and 2004. 
These results are supported by the observation of Khalifa (1994) and El-Henawy (2006). They, mentioned that, monthly and seasonal water consumptive use of citrus were decreased as affected by different type of mulching. Moreover, Abo Khaliel and El-Yassaky (1983) indicated that water consumptive use of citrus trees was greater under no-weed control than under weed control.

Table (6): Effect of drip irrigation, mulching treatments, their interaction on seasonal values of water consumptive use (WCU) and crop coefficient $(\mathrm{Kc}$ ) as well as water use efficiency (WUE) for "Anna" apple trees in 2003 and 2004 seasons.

\begin{tabular}{|c|c|c|c|c|c|c|c|}
\hline \multicolumn{2}{|c|}{ Treatments } & \multicolumn{2}{|c|}{$\begin{array}{l}\text { Total consumptive use } \\
\text { (CU) } \mathrm{m}^{3} / \mathrm{fed} \text {. }\end{array}$} & \multicolumn{2}{|c|}{$\begin{array}{c}\text { Crop } \\
\text { coefficient(KC) }\end{array}$} & \multicolumn{2}{|c|}{$\begin{array}{l}\text { Water use efficiency } \\
(\mathrm{kg} / \mathrm{fed} .) / \mathrm{m}^{3} \text { water }\end{array}$} \\
\hline Irrig. rate & $\begin{array}{c}\text { Mulching } \\
\text { type }\end{array}$ & 2003 & 2004 & 2003 & 2004 & 2003 & 2004 \\
\hline \multirow{3}{*}{$\mathrm{l}_{1}$} & Bare soil & 3258.1 & 3319.4 & 0.53 & 0.50 & 2.50 & 2.48 \\
\hline & Cut grass & 2612.9 & 2784.2 & 0.43 & 0.42 & 4.13 & 3.94 \\
\hline & Black P.E. & 2563.3 & 2691.1 & 0.42 & 0.41 & 4.36 & 4.20 \\
\hline \multirow{3}{*}{$\mathrm{I}_{2}$} & Bare soil & 2450.2 & 2500.1 & 0.40 & 0.38 & 2.59 & 2.42 \\
\hline & Cut grass & 1948.0 & 2006.5 & 0.32 & 0.30 & 4.77 & 4.39 \\
\hline & Black P.E. & 1811.8 & 1849.3 & 0.29 & 0.28 & 5.46 & 5.04 \\
\hline \multirow{3}{*}{$I_{3}$} & Bare soil & 1624.6 & 1665.5 & 0.27 & 0.25 & 2.84 & 2.62 \\
\hline & Cut grass & 1332.2 & 1363.5 & 0.22 & 0.20 & 5.26 & 4.76 \\
\hline & Black P.E. & 1265.0 & 1305.2 & 0.21 & 0.20 & 5.62 & 5.13 \\
\hline \multicolumn{2}{|c|}{ L.S.D. 0.05} & 208.44 & 190.99 & 0.032 & 0.036 & 0.829 & 0.813 \\
\hline \multirow{3}{*}{ Average } & $I_{1}$ & 2811.4 & 2931.6 & 0.46 & 0.44 & 3.66 & 3.54 \\
\hline & $\mathrm{I}_{2}$ & 2070.0 & 2118.6 & 0.34 & 0.32 & 4.27 & 3.95 \\
\hline & $\mathrm{I}_{3}$ & 1407.3 & 1446.4 & 0.23 & 0.22 & 4.57 & 4.17 \\
\hline \multicolumn{2}{|c|}{ L.S.D. 0.05} & 106.03 & 133.68 & 0.020 & 0.021 & 0.735 & 0.309 \\
\hline \multirow{3}{*}{ Average } & Bare soil & 2444.3 & 2495.0 & 0.40 & 0.38 & 2.64 & 2.51 \\
\hline & Cut grass & 1964.4 & 2051.4 & 0.32 & 0.31 & 4.72 & 4.36 \\
\hline & Black P.E. & 1880.0 & 1948.5 & 0.31 & 0.30 & 5.15 & 4.79 \\
\hline \multicolumn{2}{|c|}{ L.S.D. 0.05} & 73.19 & 55.63 & 0.010 & 0.012 & 0.156 & 0.307 \\
\hline
\end{tabular}

$I_{1}, I_{2}$ and $I_{3}=13.584,10.188$ and $6.792 \mathrm{~m}^{3}$ irrigation water/tree/year, respectively.

Soil mulching material was applied on March, $1^{\text {st }}$ in both seasons.

* Seasonal values of the crop coefficient (Kc) for ":Anna" apple trees

As for the effect of drip irrigation regime the data exhibited that, monthly water consumptive use values, were gradually decreased by reducing the rate of irrigation from 13.584 to $6.792 \mathrm{~m}^{3} /$ tree/year as illustrated in Fig. (1). Data of total consumptive use $\mathrm{m}^{3} / \mathrm{fed}$. took the same trend and the maximum values belonged to $\left(I_{1}\right)$, while the minimum values obtained with deficit irrigation rate $\left(I_{3}\right)$. This hold true in both seasons. These findings are in complete agreement with those obtained by El-Gendy and Abd El-Messeih (2002), on apple trees and El-Henawy (2006), on orange trees. However, the interaction $(I \times M)$ effects on total water consumptive use $\mathrm{m}^{3} / \mathrm{fed}$. was significant in both seasons and arranged as follow $\left(\mathrm{l}_{1} \mathrm{x}\right.$ bare soil) $>\left(\mathrm{I}_{1} \mathrm{x}\right.$ cut grass $)>\left(I_{1} \times\right.$ black P.E) $\left(I_{2} \times\right.$ bare soil $)>\left(I_{2} \times\right.$ cut grass $)>\left(I_{2} \times\right.$ black $\left.P . E\right)>\left(I_{3}\right.$ $x$ bare soil $)>\left(I_{3} \times\right.$ cut grass $)>\left(I_{3} \times\right.$ black P.E) interaction. So, ( $I_{2} \times$ cut grass) treatment could be considered the suitable one which recorded moderate seasonal water consumptive use values although it improved fruit crop 
Mady, A.A.

production as well as save applied water with $25 \%$ and using less price mulch materials.

\section{Crop coefficient $(\mathrm{Kc})$ :}

Values of seasonal Kc for "Anna" apple trees as influenced by drip irrigation (I), mulching type (M) and their interaction are presented in Table (6). It is clear that, seasonal Kc values were gradually decreased parallel to the depression of irrigation rate. The highest values was obtained under high irrigation rate $\left(I_{1}\right)$, while the lowest one was found with application of low irrigation rate $\left(l_{3}\right)$ and the differences among the three tested irrigation rates were significant in both seasons. Similar results were obtained by Doorenbos and Pruitt (1977) and Khalifa et al. (2001).

With respect to the effect of mulching, the data also revealed that, both black P.E and dry cut grass mulches recorded significant lower seasonal $K c$ values than that of bare soil without significant difference between them in 2003 and 2004 seasons. These results are in harmony with those of Khalifa et al. (1994), who found that seasonal Kc values of "Valencia" orange was obtained under soil mulching with rice straw while the highest one was found under no weed control treatment. Moreover, the interaction was significant and the highest seasonal $\mathrm{Kc}$ values obtained by $\left(\mathrm{l}_{1} \mathrm{x}\right.$ bare soil) interaction with 0.53 and 0.50 in 2003 and 2004 seasons, respectively whereas, the least values came from ( $I_{3} \times$ black P.E) or ( $l_{3} \times$ cut grass) interaction and the values of other interactions were inbetween.

\section{Water use efficiency (WUE) $\mathrm{kg} / \mathrm{m}^{3}$ :}

Water use efficiency values are used to evaluate the effectiveness of irrigation and mulching practices for maximum utilization of water supplies. It is clear from data in Table (6) that, WUE for "Anna" apple trees were significantly high by using either deficit $\left(\mathrm{I}_{3}\right)$ or moderate $\left(\mathrm{I}_{2}\right)$ irrigation rates and differences between them were not significant during 2003 and 2004 seasons. On the other hand, high irrigation rate $\left(l_{1}\right)$ recorded the least values. These findings are in line with those obtained by Fathi (1999), on "LeCont" pear, Abd El-Messeih (2000), on "Anna" apple, Abd El-Messeih and El-Gendy (2004) on "Canino" apricot and El-Henawy (2006), on "Navel" orange. They indicated a gradual decrease in WUE values due to increase the amount of applied water.

It is noticeable from the data in Table (6) that, soil mulching with black P.E or dry cut grass significantly increased WUE values as compared to bare soil due to improving fruit crop production. Difference between them was only significant in the first season. These results are in agreement with those obtained by El-Henawy (2006) who reported that, WUE values under soil mulching were higher than that under bare soil. As for the interaction, the data exhibited significant effect in both seasons and the highest WUE values always belonged to moderate or deficit irrigation rates under mulches with black P.E or dry cut grass in ( $l_{3} \times$ black P.E), ( $l_{3} \times$ cut grass), ( $l_{2} \times$ black P.E) and $\left(I_{2} \times\right.$ cut grass) combination treatments and the differences among them were always insignificant in both seasons. Thus, $\left(I_{2} \times\right.$ cut grass) considered the best combination treatment for improving fruit crop production and raising water use efficiency of Anna" apple trees under the condition of this study. 


\section{Conclusion}

The experience showed that the interaction between the rates of drip irrigation and mulching the soil surface was significant.

The study recommends the anna apple growers to use irrigation rate of $10.188 \mathrm{~m}^{3} /$ tree/year to mulch the soil surface with dry cut grass where it is the best treatment to obtain the highest yield with the best attributes of quality and reduce water consumption while increases the water use efficiency.

\section{REFERENCES}

Abd El-Messeih, W.M. (2000). Response of "Anna" apple trees to different irrigation treatments combined with three nitrogen levels for scheduling irrigation and saving water in new reclaimed soil. Ph.D. Thesis, Fac. of Agric., Alex. Univ., Egypt.

Abd El-Messeih, W.M. and R.W. El-Gendy (2004). Effect of different trickle irrigation levels based on soil matric potential on: 1. vegetative growth and yield of "Canino" apricot trees planted in sandy soils. Alex. Sci. Exch., 25(3): 465-480.

Abo-Khalid, A. and A. El-Yassaky (1983). Some irrigation guidelines for improving the farming system in ARE. FAO Project, GCP/ECY 1013/1.

Association of Official Agriculture Chemists (1990). Official Methods of Analysis. $115^{\text {th }}$ Ed. Washington D.C., USA.

Atkinson, C.J.; A.D. Webster; S.P. Vaughan; L. Taylor and G. Kingswell (2000). Interaction between root restriction, irrigation and rootstock treatments on "Queen Cox" apple trees: Effects on soil and plant water relations. J. Hort. \& Biotech., 75(4): 376-382.

Behboudian, M.H.; G.S. Lawes and K.M. Griffiths (1994). The influence of water deficit on water relation, photosynthesis and fruit growth in Asian pear (Pyrus serotina. Rehd.). Scientia Horticulturae. 60: 89-99.

Black, C.A. (1983). Methods of Soil Analysis part I and II. Amer. Agron. Inc. Publ., Madison, Wisconsin. USA.

Doorenbose, J. and W.O. Pruitt (1977). Crop water requirements. Irrigation and Drainage paper No. 24, FAO. Rome, Italy, pp. 144.

Eble, R.C.; E.L. Proebsting and M.E. Patterson (1993). Regulated deficit irrigation may alter apple maturity, quality and storage life. HortSci., 28(2): 141-143.

El-Gendy, R.W. and W.M. Abd El-Messeih (2002). Water consumption and apple trees productivity as affected by soil water suction and irrigation scheduling. Monufiya J. Agric. Res., 27(2): 391-405).

El-Henawy, A.S. (2006). Effect of drip irrigation and soil mulching on some soil properties, yield and quality of "Navel" orange trees at North Delta. Ph.D. Thesis, Fac. Agric., Kafr El-Sheikh, Tanta Univ., Egypt.

FAO (1977). Localized irrigation and drainage. Paper No. 36.

FAO (1984). Agroclimatological data for Africa, Vol. 2. FAO plant production and protection series. No. 22. Rome.: Food and Agriculture Organization of the United Nation. 
Mady, A.A.

FAO (1990). Report on the expert consultation on revision of FAO methodologies for crop water requirements. Land and Water Devel. Div.; Rome, Italy.

George, A.B. and R.J. Nissen (2002). Effect of drought on fruit set, yield and quality of custard apple (Annona spp. hybrid) "African pride" plants $\mathrm{J}$. Hort. \& Biotech., 77(4): 418-427.

Hansen, V.E.; O.W. Israelsen and Q.E. Stringhavm (1980). Irrigation principle and practices $4^{\text {th }}$ Ed. John. Wiley and Sons. Inc. New York.

Hifny, H.A.; G.A. Baghday and M.S. Arafa (1994). Response of growth and yield of "Banaty" grape vine to soil mulchs as a tool for weed control. Egypt. J. Hort., 21(1): 81-92.

Higgs, K.H. and H.G. Jones (1991). Water relations and cropping of apple cultivars on a dwarfing rootstock in response to imposed drought. J. Hort. Sci. 66(3): 367-379.

Hipps, N.A. (1997). Effect of nitrogen, phosphorus water and pre-planting soil sterilization on growth and yield of "Queen Cox"/M.9 apple trees. Acta Horticulturae. 448: 125-131.

Israelsen, O.W. and V.E. Hanson (1962). Irrigation principles and practices $3^{\text {rd }}$ Ed. John Wiley and Sons. Inc. New York.

Khalifa, M.R. (1994). Effect of different types of mulching on water consumptive use of "Valencia" orange trees. J. Agric. Res. Tanta Univ., 20(3): 591-602.

Khalifa, M.R.; S.A. Dawood and S.M. Zeerban (2001). Yield, fruit quality and water consumptive use of "Washington Navel" orange trees in relation to different flooding irrigaiton methods at Kafr El-Sheikh Province. J. Agric. Res. Tanta Univ., 27(2): 358-370.

Kulte, A. (1986). Methods of Soil Analysis Part. 1-2 nd ed. ASA and SSSA. Madison.

Ministry of Agriculture and Land Reclamation (2005). Agricultural Economics Annual Report, Cairo, Egypt.

Mpelasoka, B.S.; M.H. Behboudian and T.M. Mills (2001). Water relations, photosynthesis, growth, yield and fruit size of "Braeburn" apple: responses to deficit irrigation and to crop load. J. Hort. \& Biotech., 76(2): 150-156.

Naor, A.; H. Hupert; Y. Greenblate; M. Peres; A. Kaufman and I. Klein (2001). The response of nectarine fruit size and middy stem water potential to

irrigation level in stage III and crop load. J. Amer. Soc. Hort. Sci., 126(1): 140143.

Pande, K.K.; D.C. Dimri and P. Kamboj (2005). Effect of various mulches on growth, yield and quality attributes of apple. Indian J. Hort. 62(2): 145147.

Shahein, A.H.; M.B. El-Sabrout; M.M. Yehia and W.M. Abd El-Messeih (2002). Effect of drip irrigation and nitrogen fertilization on: III. The yield, fruit quality and saving water of :"Anna" apple trees grown in new reclaimed soils. J. Agric. Sci. Mansoura Univ., 27(4): 2431-2450.

Singh, S.R.; A.K. Sharma and K.K. Srivastava (2005). Response of mulches and antitranspiration on moisture conservation, yield and quality of 
apple (Malus domestica, Borkh) cv Red Delicious under rain fed conditions of Kashmir valley. Environment and Ecology. 23(3): 572-576.

Snedecor, G.W. and W.G. Cochran (1990). Statistical Methods. $7^{\text {th }}$ Ed. lowa State Univ., USA. p. 593.

Tahir, I.I.; E. Johansson and M.E. Olssson (2005). Ground cover materials improved quality and storability of "Aroma" apples. HortSci., 40(5): 14165-1420.

Verma, M.L.; S.P. Bhardwaj; B.C. Thakur and A.R. Bhandria (2005). Nutritioanl and mulching studies in apple. Indian J. Hort. 62(4): 332335.

Zayan, M.A. (1991). Effect of some mulching materials on growth, leaf mineral content, fruit set, preharvest fruit drop, FND, fruit quality and creasing in "Washington Navel" orange trees. Alex. J. Agric. Res. 36(2): 183-198.

Zayan, M.A. and E. Morsy (1989). Studied on rest period of "Anna" apple buds under the groclumatic conditions in North Delta. J. Agric. Res. Tanta Univ., 15(1): 54-64.

Zayan, M.A.; S.M. Zeerban; E. Morsey and G.B. Mikhael (1994). Effect of some soil mulching on vegetative growth, yield, fruit quality and leaf mineral contents of "Anna" apple trees grown in calcareous soil. J. Agric. Res. Tanta Univ., 20(4): 721-730.

Zeerban, S.M. (2004). Vegetative growth, yield and fruit quality of "Thompson seedless" grape vines as affected by some soil mulching materials. J. Agric. Sci. Mansoura Univ., 29(6): 3515-3529. 
Mady, A.A.

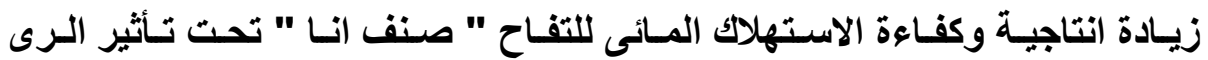

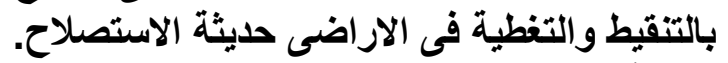

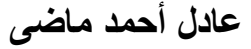

معهذ بحوث إدارة المياه وطرق الرى ـ المركز القومى لبحوث المياه ـ القاهرة ـ مصر.

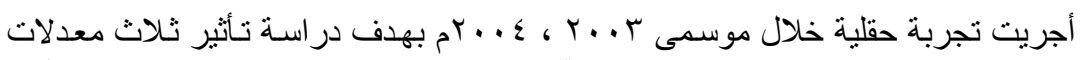

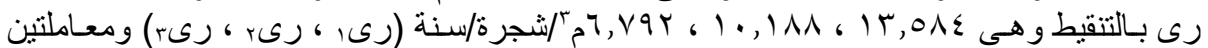

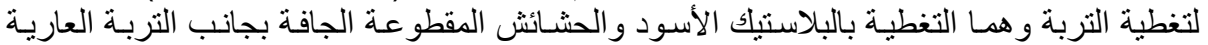

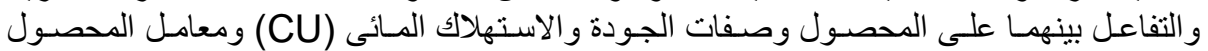

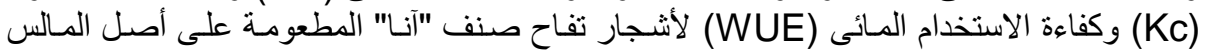
و النامية في تربة طميية رملية بمنطقة البستان بمحافظة البحان البحيرة.

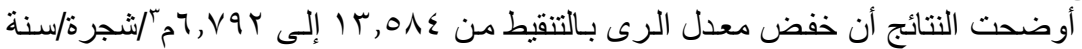

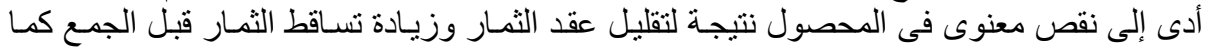

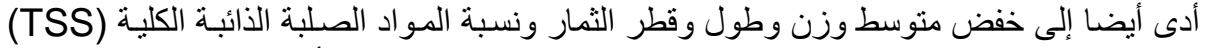

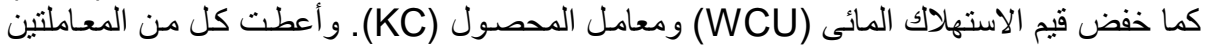

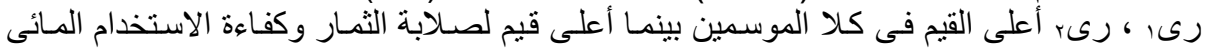

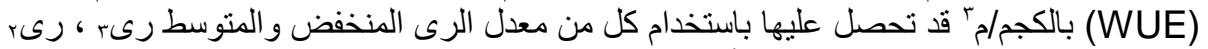
بدون فروق معنويـة بينهما ومن جهة أخرى فإن الحموضـة الكلية لم تتاثر معنويـا بمعدلات الرى الرى الرى

أدت تغطية سطح التربة بكل من البلاستيك الأسود أو الحشائش المقطو عة الجافة إلى إنتاج المختبرة

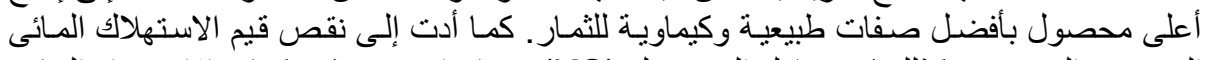

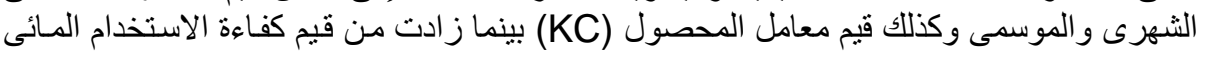

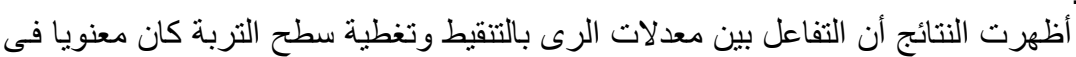
(WUE)

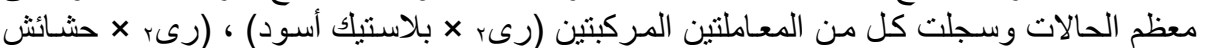

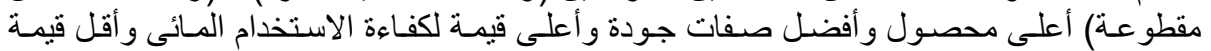
للاستهلاك المائى فى كل من سنتى العى الدر اسة.

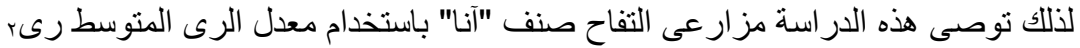

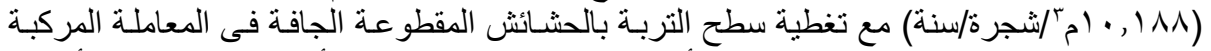

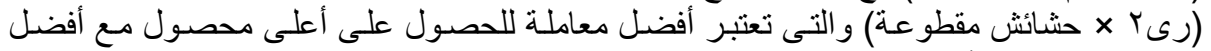

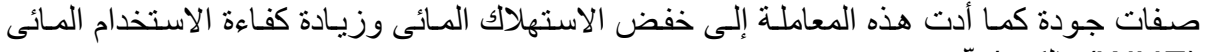

